DOI

M. A. Stashkevych, S. V. Zyablitsev

O. O. BOHOMOLETS NATIONAL MEDICAL UNIVERSITY, KYIV

\title{
THE ROLE OF VARIOUS NUCLEOSIDES IN THE ACTIVATION OF 5-FLUOROURACIL IN GASTRIC ADENOCARCINOMA
}

The main metabolic pathways of anticancer drug 5-fluorouracil (5-FU) include its transformation to active metabolites via attaching the naturally occurring pentose phosphates. It is known that different tissues use different nucleosides as donators of pentose phosphates for activation of 5-FU. The objective of the present study was determination of pentose phosphate sources for 5-FU metabolic transformation in gastric adenocarcinoma and normal adjacent mucosa. 5-FU was incubated in vitro with one of the nucleosides (adenosine, uridine, thymidine) and tumor or adjacent tissue homogenates obtained from patients with gastric adenocarcinoma. The concentration of initial metabolites and the products of the pentose exchange reaction in the samples was determined before and after the incubation by means of HPLC. Both in systems with tumor and normal tissue homogenates the reaction of 2'-deoxyribose exchange between thymidine and 5-FU occurred resulting in equimolar production of 5-fluoro-2'deoxyuridine and thymine. In the model system containing adenosine free ribose-1-phosphate was formed; however, the formation of nucleoside from 5-FU did not arise. It was also shown that mutual incubation of 5-FU and uridine with gastric tissues homogenates did not result in the formation of 5-FUd. Among the examined natural nucleosides it is only thymidine that serves as pentose phosphate source for the first step of the activation of 5-FU in gastric adenocarcinoma and normal adjacent tissue.

KEY WORDS: 5-fluorouracil, pentose phosphate, adenocarcinoma, nucleoside.

INTRODUCTION. Cytostatic drug 5-fluorouracil (5-FU) was synthesized in the middle of the previous century and since that time has been widely used for treatment of different types of oncological diseases including gastric cancer [1]. 5-FU itself is not an active substance, however, being a prodrug which is activated by transforming to different nucleotides via several pathways:

1) addition of ribose-1-phosphate (rib-1-P) or 2'-deoxy-ribose-1-phosphate (d-rib-1-P) under the action of thymidine phosphorylase (TP) or uridine phosphorylase (UP). Traditionally UP is considered to be specific only to ribonucleosides and TP - to deoxyribonucleosides. However, researchers Kouni et al. [2] have shown that in different tissues these enzymes have different substrate specificity and TP can catalyze the activation of 5-FU via addition of d-rib-1-P;

2) direct transfer of ribose phosphate from phosphoribosyl pyrophosphate (PRPP) to 5-FU catalyzed by orotate phosphoribosyl transferase $[3,4]$.

Taking in account the fact that 5-FU acts only when transformed to active metabolites, the efficiency of this drug is determined by the intensiveness of its activation in human cells. First of all this parameter depends on the activity of the main metabolic

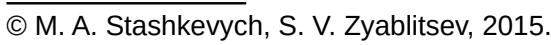

enzymes of 5-FU - TP and UP. Various studies are devoted to the research of these enzymes activity or expression in different tissues and their relation to the efficiency of 5-FU-based chemotherapeutic regimens $[5,6]$.

Meanwhile, there is another factor which determines the rate of activation of 5-FU in the cell, namely the presence of co-substrates essential for the action of 5-FU activating enzymes, e.g. various pentose phosphates and their donors. Pentose phosphates in the cell are synthesized from naturally occurring nucleosides or from glucose which is transformed to ribose-5-phoshate in the pentose-phosphate pathway. Further ribose-5-phospate binds to ATP to form PRPP. Breakdown of the nucleosides results in the formation of either rib-1-P or d-rib-1-P. [7]. The data regarding the role of each of these pentose sources for activation of 5-FU in various species are present in the scientific literature but not properly systemized; moreover, the predominance of the activation pathways of 5-FU varies in different organisms [4, 7, 8]. It is still unknown which sources of pentose phosphates are used for the activation of 5-FU in gastric cancerous and normal tissues. The aim of the present study was to determine the naturally occurring nucleosides which serve as pentose phosphate donators for the first step of 5-FU activation in gastric adenocarcinoma and normal adjacent tissue. 
METHODS OF RESEARCH. The natural nucleosides: adenosine, thymidine and uridine were used as the sources of pentose phosphates in the present study. For the evaluation of their participation in the process of 5-FU activation we used the model in vitro systems which contained one of the abovementioned nucleosides, 5-FU and homogenates of tumor or adjacent normal stomach mucosa. Tissues were obtained during the gastrectomy in 10 patients ( 6 males) aged from 38 to 76 years old at different stages of gastric cancer $(T=2-4)$.

Reaction mixture consisted of 5-FU and nucleoside (adenosine, thymidine or uridine) in the equimolar concentration dissolved in the phosphate buffer $(\mathrm{pH}=7.4)$ with mercaptoenthanol. Reaction was initiated by the addition of tissue homogenate. Immediately after initiation of the reaction as well as in 45 minutes of incubation at $37^{\circ} \mathrm{C}$ the reaction was terminated by the addition of acetonitrile to the samples. The precipitated protein was removed by means of centrifugation of this mixture for 15 minutes at $12000 \mathrm{~g}$. Then acetonitrile was extracted from the samples by means of chloroform.

The concentrations of the initial reactants (5-FU, adenosine, thymidine, uridine) and reaction products (5-FUd, 5-FdUd, inosine, hypoxantine, thymine, uracil) were determined using HPLCsystem (Konikrom, Spain) with UV-spectrometer at $260 \mathrm{~nm}$. The typical chromatogram for the system "5-FU+thymidine" incubated with homogenate of gastric adenocarcinoma is presented in Figure 1.

The calculation of the concentrations of all metabolites was performed using the calibration curves constructed by 5 different concentrations of these substances after the preparation described above.

RESULTS AND DISCUSSION. The incubation of the system containing adenosine and 5-FU resulted in the accumulation of the products of adenosine breakdown - inosine and hypoxantine, 5-FUd being barely formed (Figure 2).

In the homogenates of all patients the accumulation of reaction products and loss of initial substrates was uniform; there were only differences in the absolute values of concentration change. As for example, in the system containing homogenate of adenocarcinoma of patient $A$. the concentration of adenosine decreased by $(245.3 \pm 2.9) \mathrm{mcmol} / \mathrm{l}$ after 45 minutes of incubation, while the increase of inosine and hypoxantine level made up $60 \%$ and $23 \%$ of adenosine loss respectively. The level of 5-FU barely changed during the incubation, the delta of its concentration amounted to $(6.3 \pm 2.5) \mathrm{mcmol} / \mathrm{l}$. There was no statistical difference between the changes of all metabolites concentrations in the systems containing tumor tissue homogenates and systems with normal tissue homogenates.

In the system " 5 -FU+thymidine" the significant equimolar loss of initial metabolites concentration and corresponding increase of the reaction products - 5-FdUd and thymine was observed (Figure 3).

As exemplified in figure 3 , in the system with patient A.'s tumor tissue homogenate the loss of 5-FU and thymidine concentration amounted to (98.0 \pm 3.0$)$ and $(91.3 \pm 4.3) \mathrm{mcmol} / / \mathrm{lrespectively}$ and increase of $5-F d U d$ and thymine was $(70.0 \pm 0.7)$ and $(77.0 \pm 0.8) \mathrm{mcmol} / \mathrm{l}$ respectively. The accumulation of 5-FdUd and thymine was equimolar in all probes, there were no statistical differences between these values according to non-parametric Wilcoxon test. For the tumor tissue the mean change of all metabolites concentration was $30 \%$ higher than in normal adjacent mucosa, differences were statistically significant at $p<0.05$.

Figure 4 presents the change of metabolites concentration in the system containing 5-FU and uridine.



Figure 1. Typical chromatograms of the samples of system "5-FU+thymidine" before $\left.{ }^{*}\right)$ and after $\left(^{* *}\right)$ the incubation with homogenate of gastric adenocarcinoma. 


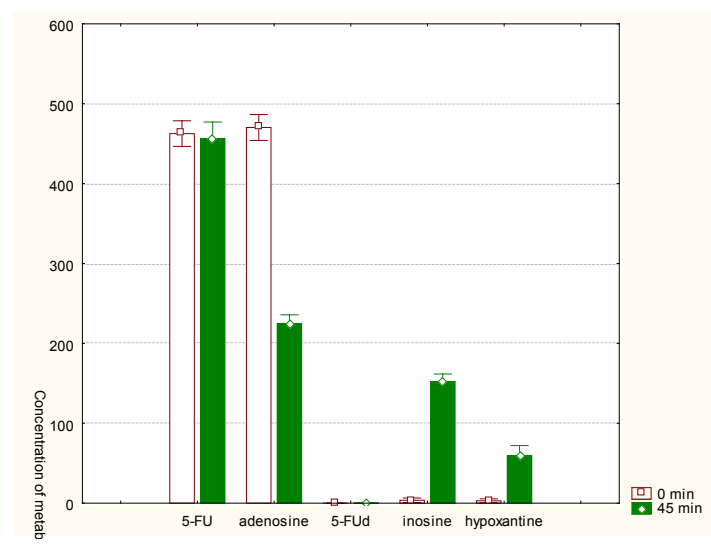

Figure 2. Metabolites concentration before ( $0 \mathrm{~min})$ and after (45 $\mathrm{min}$ ) the incubation of the system "5-FU+adenosine" with homogenate of gastric adenocarcinoma of patient $A$.

For this system the increase of reaction products has not been detected in any probe. The level of the initial substances slightly decreased in all samples, for patient $A$. the change of $5-\mathrm{FU}$ and uridine concentration amounted to $(5.0 \pm 3.5)$ and (4.7 \pm 2.1$) \mathrm{mcmol} / \mathrm{l}$.

The mechanism of reactions in the above described systems for purine and pyrimidine nucleosides differs in the number of stages and enzymes involved in these processes. The cleavage of adenosine to inosine and ammonia is catalyzed by adenosine deaminase and further breakdown of inosine to hypoxantine and rib-1-P is provided by purine nucleoside phosphorylase. Rib-1-P obtained as a result of inosine phosphorolysis may be a substrate for 5 -FU activation $[4,7]$. As is proven in the system " $5-\mathrm{FU}+$ adenosine" hypoxantine was obviously synthesized hence the formation of rib1-P arose as well. In the meantime there was no 5-FUd increase observed therefore free rib-1-P had not been attached to 5 -FU. This fact proves that 5 -FU activation by means of pentose phosphate exchange with adenosine is impossible.

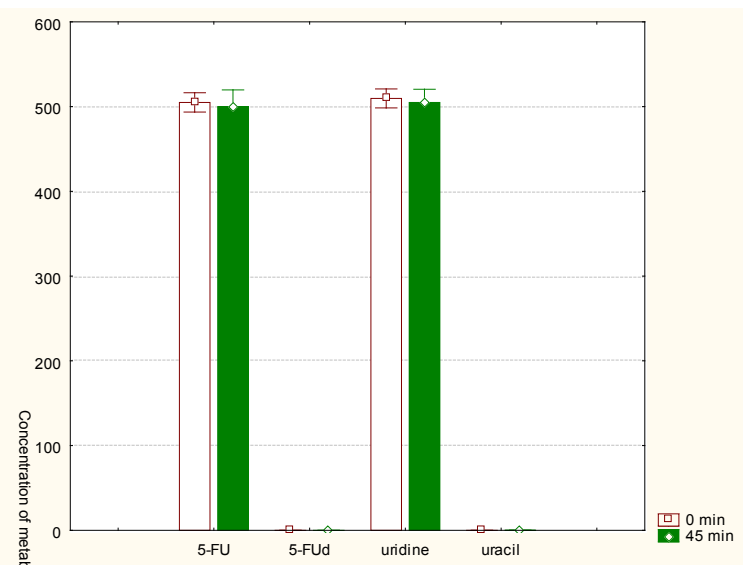

Figure 4. Metabolites concentration before (0 min) and after (45 $\mathrm{min}$ ) the incubation of the system "5-FU+uridine" with homogenate of gastric adenocarcinoma of patient $A$.

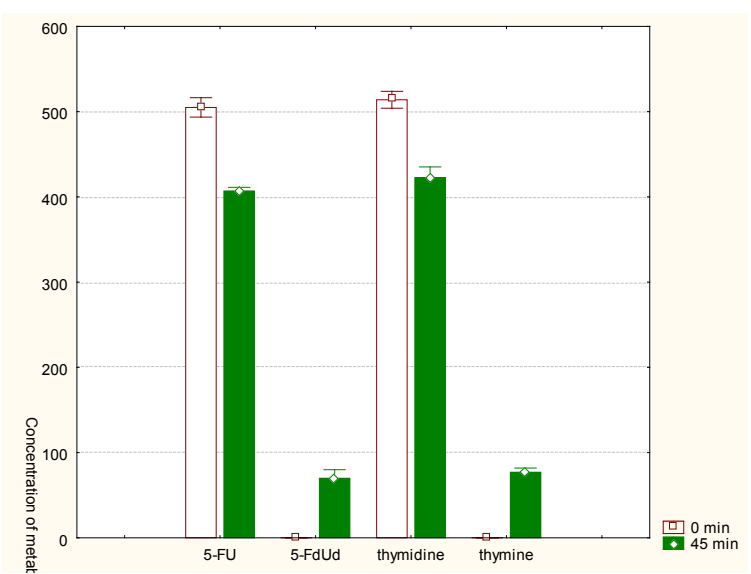

Figure 3. Metabolites concentration before ( $0 \mathrm{~min})$ and after (45 $\mathrm{min}$ ) the incubation of the system "5-FU+thymidine" with homogenate of gastric adenocarcinoma of patient $A$.

For pyrimidine nucleosides ribose exchange reactions are carried out in one stage whereas pyrimidine nucleoside phosphorylases have both phoshorylase and transferase activities, so they are able to transfer pentose phosphates from one pyrimidine base to another [9].

Results of the present study showed that there was no rib-1-P exchange in the system "5-FU+uridine". Data from the similar study on Erlich ascites carcinoma testify that interaction of 5-FU and uridine led to the formation of active metabolites of the drug [8]. It is obvious that in the present study the enzymatic systems of gastric tissues were unable to transfer rib-1-P from uridine to 5-FU so the reason of inconsistency of our data and results of other authors was the usage of different tissues as the research objects.

At the same time there was equimolar accumulation of reaction products - 5-FdUd and thymine in the system containing 5-FU and thymidine. Whereas the loss of 5-FU in the presence of thymidine was an order greater than in the presence of uridine. These facts give evidence that thymidine is used by the cancer and normal gastric cells for the activation of 5-FU. It is logically to opine that at saturation of tissues with 5-FU which occurs e.g. at intraarterial administration, this drug would "capture" pentose from thymidine thereby depleting the pool of this nucleoside in the cells.

Thymidine was the only nucleoside used in the present study that contained the residue of 2 '-deoxyribose. Since the cleavage of d-rib-1-P is mainly catalyzed by TP the observed transformation of 5-FU in the presence of thymidine was provided by the catalytic activity of this enzyme. As is proven in this study the change of all metabolites concentrations in the system "5-FU+thymidine" with tumor homogenate was significantly higher than in the system with normal adjacent tissue homogenate. It might be explained by the fact that in solid 
tumors in different cancer types the hyperexpression of TP in the comparison with normal tissues is observed [9].

It is known [10] that thymidine is used by cells for the "salvage" pathway of thymidilate. That is why the change of thymidine level may lead to the change in the concentration of dTMP, dTDP and dTTP. The well-known mechanism of action of 5-FdUMP which is the active form of 5-FU involves inhibition of thymidilate synthase that leads to the decrease of the thymidine nucleotides amount and failure of DNA synthesis [11]. However, as it was shown in the present study 5-FU itself without transformation to 5-FdUMP is able to decrease the concentration of thymidine thus eliminating the possibility of dTMP, dTDP and dTTP synthesis. In other words, this influence of 5-FU may be alternative to the generally accepted mechanisms of action of this drug which is realized directly without biotransformation to active metabolites.

On the other hand, the pharmacological modulation of 5-FU metabolism based on usage of various sources of pentose phosphates provides the increase of its clinical effectiveness. Investigation of the possibility of 5-FU effects modulation by means of synthetic nucleoside analogs has shown that azidothymidine, 3'-deoxythymidine, 3'didehydrothymidine have the stimulating effect on 5-FU cytotoxicity when applied to the mammary and intestine cancer cell lines. 5-Hydroxymethyl2'-deoxyuridine and modified analogs of inosine enforce the effects of 5-FU in the solid tumors cell lines [12-14]. The fact of 5-FU activation with the help of d-rib-1-P in gastric adenocarcinoma and normal mucosa shown in this study may underlie the argumentation of the usage of 5-FU in the combination with synthetic deoxyribonucleosides for the treatment of gastric cancer.

CONCLUSIONS. Thus, it was stated that among the examined natural nucleosides the source of pentose phosphate for 5-FU activation in gastric adenocarcinoma and normal adjacent tissue is thymidine; uridine and adenosine are unable to donate pentose residue to 5-FU in these tissues. This effect may lead to the depletion of intracellular thymidine pool that would contribute to the general cytotoxic action of 5-FU, while in tumors this influence might be greater than in normal tissues.

\section{REFERENCES}

1. Treatment of gastric cancer / M. Orditura, G. Galizia, V. Sforza [et al.] // World J. Gastroenterol. - 2014. Feb. 21; 20 (7). - P. 1635-1649.

2. el Kouni M. H. Differences in activities and substrate specificity of human and murine pyrimidine nucleoside phosphorylases: implications for chemotherapy with 5-fluoropyrimidines / M. H. el Kouni, M. M. el Kouni, F. N. Naguib // Cancer Res. - 1993. - Aug. 15; 53 (16). P. 3687-3693.

3. PharmGKB summary: fluoropyrimidine pathways / C. F. Thorn, S. Marsh, M. W. Carrillo [et al.] // Pharmacogenet Genomics. - 2011. - Apr.; 21 (4). - P. 237-242.

4. Mascia L. Activation pathways of 5 -fluorouracil in rat organs and in PC12 cells / L. Mascia, P. L. Ipata // Biochem. Pharmacol, - 2001. - Jul. 15; 62 (2). P. 213-218.

5. Hirashima Y. Predicting drug efficacy-fluorinated pyrimidines (fluorouracil, S-1 and capecitabine) / Y. Hirashima, K. Shirao // Gan To Kagaku Ryoho. - 2012. Nov.; 39 (11). - P. 1603-1607.

6. Correlated analysis of 5 fluorouracil metabolic enzymes with tumor response after SOX regimen neoadjuvant chemotherapy in advanced gastric cancer I T. Li, M. Liang, J. Yuan [et al.] // Zhonghua Yi Xue Za Zhi. - 2014. - Jan. 14; 94 (2). - P. 127-130.

7. Pentose phosphates in nucleoside interconversion and catabolism / M. G. Tozzi, M. Camici, L. Mascia [et al.] // FEBS J. - 2006. - Mar.; 273 (6). - P. 1089-1101.
8. Ribose-transfer activity from uridine to 5-fluorouracil in Ehrlich ascites tumor cells / Y. Nabeya, K. Isono, Y. Moriyama, S. Fujimura // Jpn J Cancer Res. - 1990. Jun.; 81 (6-7). - P. 692-700.

9. The dual role of thymidine phosphorylase in cancer development and chemotherapy / A. Bronckaers, F. Gago, J. Balzarini, S. Liekens // Med. Res. Rev. - 2009. - Nov.; 29 (6). - P. 903-953.

10. Thymidine kinases share a conserved function for nucleotide salvage and play an essential role in Arabidopsis thaliana growth and development / J. Xu, L. Zhang, D. L. Yang [et al.] // New Phytol. - 2015. - Jul. 2.

11. Mechanisms of action of FdUMP: metabolite activation and thymidylate synthase inhibition / I. V. Bijnsdorp, E. M. Comijn, J. M. Padron [et al.] // Oncol. Rep. - 2007. - Jul.; 18 (1). - P. 287-291.

12. Potentiation of 5-fluorouracil efficacy. Molecular mechanisms playing a role in the cytotoxic action of 5-fluorouracil and 5-ethyl-2'-deoxyuridine (EUdR) combination / C. Katona, F. Timar, J. Olah [et al.] // Magy Onkol. - 2004. - 48 (3). - P. 243-251.

13. Cytotoxic interactions of 5-fluorouracil and nucleoside analogues in vitro / Y. X. Li, P. A. Coucke, N. Paschoud, R. O. Mirimanoff // Anticancer Res. 1997. - Jan.; 17 (1A). - P. 21-27.

14. Synergistic enhancement of 5-fluorouracil cytotoxicity by deoxyuridine analogs in cancer cells / Y. Matsumoto, V. Rodriguez, T. A. Whitford [et al.] // Oncoscience. - 2015. - 2 (3). - P. 272-284. 


\section{РОЛЬ РІЗНИХ НУКЛЕОЗИДІВ В АКТИВАЦІЇ 5-ФТОРУРАЦИЛУ ПРИ АДЕНОКАРЦИНОМІ ШЛУНКА}

\section{Резюме}

Основні шляхи біотрансформації протипухлинного препарату 5-фрторурацилу (5-ФУ) включають його перетворення на активні метаболіти шляхом приєднання природних пентозофоссратів. Відомо, що в різних тканинах різні нуклеозиди слугують донорами пентозофоссратів для активації 5-ФУ. Метою цього дослідження було визначити джерела пентозофоосратів, які використовуються клітинами аденокарциноми та нормальної суміжної слизової оболонки шлунка для метаболічної трансорормації 5-Фу. Проводили інкубацію 5-ФУ з одним із нуклеозидів (аденозином, тимідином та уридином) in vitro при додаванні гомогенату пухлинної або суміжної тканини, отриманих від пацієнтів з аденокарциномою шлунка. Концентрацію вихідних речовин та продуктів реакції обміну пентозофоссфатами визначали до і після інкубації проб методом ВEPX. Як у системі з гомогенатом пухлинної тканини, так і в системі з нормальною слизовою оболонкою шлунка відбувалась реакція обміну 2'-дезоксирибозо-1-фросфратом між тимідином і 5-ФУ, яка призводила до еквімолярного приросту концентрації 5-фртор-2'-дезоксиуридину та тиміну. В модельній системі, яка містила аденозин, утворювався вільний рибозо-1-фросфрат, однак при цьому не спостерігали перетворення 5-ФУ на нуклеозид. При сумісній інкубації 5-ФУ з уридином та гомогенатами тканин шлунка не відбувалося синтезу 5-фрторуридину. Серед досліджених природних нуклеозидів лише тимідин слугує джерелом пентозофосфату для першого етапу активації 5-ФУ в аденокарциномі та нормальній слизовій оболонці шлунка.

КЛЮЧОВІ СЛОВА: 5-фрторурацил, пентозофосфрат, аденокарцинома, нуклеозид.

М. А. Сташкевич, С. В. Зяблицев НАЦИОНАЛЬНЫЙ МЕДИЦИНСКИЙ УНИВЕРСИТЕТ ИМЕНИ А. А. БОГОМОЛЬЦА, КИЕВ

\section{РОЛЬ РАЗНЫХ НУКЛЕОЗИДОВ В АКТИВАЦИИ 5-ФТОРУРАЦИЛА ПРИ АДЕНОКАРЦИНОМЕ ЖЕЛУДКА}

\section{Резюме}

Основные пути биотрансформации противоопухолевого препарата 5-фрторурацила (5-Фу) включают его превращение в активные метаболиты путем присоединения естественных пентозофросфратов. Известно, что в разных тканях разные нуклеозиды служат донорами пентозофросфратов для активации 5-ФУ. Целью этого исследования было определить источники пентозофросфратов, которые используются клетками аденокарциномы и нормальной смежной слизистой оболочки желудка для метаболической трансформации 5-ФУ. Проводили инкубацию 5-ФУ с одним из нуклеозидов (аденозином, тимидином и уридином) in vitro при добавлении гомогената опухолевой или смежной ткани, полученных от пациентов с аденокарциномой желудка. Концентрацию исходных веществ и продуктов реакции обмена пентозофоосратами определяли до и после инкубации проб методом ВЭРХ. Как в системе из гомогенатом опухолевой ткани, так и в системе с нормальной слизистой оболочкой желудка происходила реакция обмена 2'-дезоксирибозо1-фросфратом между тимидином и 5-ФУ, которая приводила к эквимолярному приросту концентрации 5-сртор-2'-дезоксиуридина и тимина. В модельной системе, которая содержала аденозин, образовывался свободный рибозо-1-фроссрат, однако при этом не наблюдали превращения 5-ФУ в нуклеозид. При совместной инкубации 5-ФУ с уридином и гомогенатами тканей желудка не происходило синтеза 5-фрторуридина. Среди исследованных естественных нуклеозидов лишь тимидин служит источником пентозофоссрата для первого этапа активации 5-ФУ в аденокарциноме и нормальной слизистой оболочке желудка.

КЛЮЧЕВЫЕ СЛОВА: 5-фторурацил, пентозофосфрат, аденокарцинома, нуклеозид.

Received 15.05.15

Address for correspondence: M. A. Stashkevych, O. O. Bohomolets National Medical University, Peremogy Ave. 34, Kyiv, 03055, Ukraine, e-mail: matviyenko.maryna@gmail.com. 